\title{
Complaints concerning communication reported by users of healthcare in a specific region in Sweden
}

\author{
Emina Hadziabdic ${ }^{* 1}$, Gina Higginbottom ${ }^{2}$ \\ ${ }^{1}$ Department of Health and Caring Sciences, Faculty of Health and Life Sciences, Linnaeus University, Sweden \\ ${ }^{2}$ Faculty of Nursing, University of Alberta, Canada
}

Received: December 14, 2014

Accepted: February 2, 2015

Online Published: April 10, 2015

DOI: $10.5430 /$ jha.v4n3p39

URL: http://dx.doi.org/10.5430/jha.v4n3p39

\begin{abstract}
Introduction: Effective communication between patients and healthcare staff is important in all healthcare services. Previous studies investigating criticism and complaints concerning treatment reported by patients and relatives in a healthcare context point to the most common complaints were unsatisfactory information, unsatisfactory respect and unsatisfactory empathy, but further investigation is needed. Objective: The aim of this study was to explore complaints reported by patients and relatives in a county council area in the context of communication between patients and healthcare staff, and to investigate the impact complaints can have on the safety and quality of healthcare.

Methods: An exploratory descriptive design was used with a participatory approach. 115 complaints from patients and relatives, collected from various contexts relating to healthcare, were analyzed through qualitative content analysis.

Results: Four categories emerged from the analysis of complaints: 1) inadequate communication; 2) inadequate individualistic and holistic healthcare; 3) unprofessional attitude of healthcare staff; and 4) the complaints had both a negative and positive impact on the organization of healthcare. The study showed that complaints were related to a lack of adequate verbal and written communication, the patients' feelings that the healthcare staff did not taking their experiences seriously, and an unprofessional, indifferent and discriminatory attitude among the healthcare staff. The complaints had both a negative and positive impact on the organization of healthcare.

Conclusions: This study highlights how it is possible to learn from complaints about healthcare, and demonstrates that this is a prerequisite for improving healthcare practice. Knowledge about where healthcare practice is failing can be increased, and this can be fed into policies for patient safety and quality healthcare.
\end{abstract}

Key Words: Complaints, Patient-health staff communication, Patient safety, Quality healthcare, Participatory research, Qualitative content analysis

\section{INTRODUCTION}

Effective communication between patients and healthcare staff is important in all healthcare services ${ }^{[1,2]}$ and has impacts on patients' satisfaction with healthcare ${ }^{[3,4]}$ and selfmanagement of chronic illness. ${ }^{[5]}$ In contrast, communication barriers can lead to poorer standards in patient care. ${ }^{[2]}$ It has previously been noted that a large proportion of patients' complaints about healthcare involve a lack of communication with healthcare professionals, ${ }^{[6]}$ and that this may be related to patients' anxiety and fear, the burden of work for healthcare staff, fear of litigation, fear of physical or verbal abuse, and unrealistic patient expectations. ${ }^{[7]}$ An previous qualita-

\footnotetext{
* Correspondence: Emina Hadziabdic; Email: emina.hadziabdic@1nu.se; Address: Department of Health and Caring Sciences, Faculty of Health and Life Sciences,Linnaeus University, SE-351 95 Växjö, Sweden.
} 
tive study focused on complaints by patients and relatives in the context of healthcare encounter and communication ${ }^{[8]}$ described that unsatisfactory information, unsatisfactory respect and unsatisfactory empathy were the most common complaints, but further study is needed. This study is therefore important, as it will explore communication-related complaints from patients and relatives in a county council area, and will consider the impact complaints can have on quality and safety in healthcare. The investigation is important in terms of individualised and holistic care which addresses patient autonomy and safety, access to care, and the quality of healthcare for all individuals and their families. ${ }^{[9,10]}$

It has been shown that criticism from patients ${ }^{[11,12]}$ or from healthcare professionals in the wake of adverse events is underreported. ${ }^{[12,13]}$ However, previous systematic literature study ${ }^{[14]}$ focused on patients complaints found that the most common problems were about treatment and communication. Previous qualitative research from patients end relatives perspective investigated the complaints about physicians behavior found the most common complaints were disagreement about expectations of care, distrust, perceived unavailability, ${ }^{[15]}$ insufficient information, insufficient respect ${ }^{[8,15]}$ and insufficient empathy. ${ }^{[8]}$ Further, previous qualitative research $^{[16]}$ on adverse events concerning communication in healthcare has tended to focus on exploring problems in the use of interpreters, and the consequences of problems with healthcare staff in a particular primary healthcare centre. The study indicated that the main problems were related to language and organization issues. In this study, patients' and relatives' complaints were evaluated by reflecting on their subject matter and on how the complaints could be understood. Furthermore, the paper offers a unique opportunity to analyse in detail how patients and relatives perceive communication problems, in the hope that this can reduce errors and contribute to safe, high-quality healthcare practices and organization. The aim of this study was therefore to explore complaints about communication between patients and healthcare staff which were reported by patients and relatives in a county council area, and to consider the impact these complaints might have on the safety and quality of healthcare.

\section{METHOD}

\subsection{Design}

An exploratory descriptive design was used, with a participatory approach which emphasises the importance of partnerships between researchers and community throughout the research process. It helps to gather a variety of viewpoints, and allows researchers to design and implement projects which will have greater buy-in and support from those af- fected by the research process and the implementation of the research findings. ${ }^{[17]}$

\subsection{Setting}

The study focused on a county council in Sweden which is responsible for approximately 185,887 inhabitants in the region. ${ }^{[18]}$ The council's healthcare system included public and private healthcare, public dental care, public healthcare for disabled people, public rehabilitation and public psychiatric care for children (BUP).

Healthcare in the area was subject to the Swedish Health and Medical Services Act, ${ }^{[9]}$ the stated goal of which is to provide high-quality and accessible healthcare for all individuals and their families. It also stipulates that all healthcare staff are to be involved in systematic work on quality. ${ }^{[19]}$ Patients can send their complaints to the National Board of Health and Welfare or to the Patients' Advisory Committee (Patientnämnd). The role of the Patients' Advisory Committee involves: 1) providing patients and their relatives with the information they need about healthcare; 2) promoting contact between patients and healthcare staff; 3) connecting patients to the appropriate authority; and 4) enabling patients to submit suggestions, criticism and complaints to the various authorities. $^{[20]}$

\subsection{Data collection}

The first author contacted head of the county council's to report an increasing number of negative events relating to communication between patients and healthcare staff, and to ask for an investigation. The first author was given access to existing complaints. The head of the county council was contacted for permission to conduct the study, and when this was granted, copies of the incident reports were handed over to the researcher in anonymous form.

Documents relating to adverse events had been written by patients and relatives in 2011 and 2012. They included 115 complaints concerning problematic situations which involved the attitude of healthcare staff towards patients and relatives (see Table 1).

\subsection{Ethical considerations}

The study followed Swedish law in terms of the regulation of ethics in research involving people. ${ }^{[21]}$ The study was also implemented according to the ethical principles stated in the Declaration of Helsinki. ${ }^{[22]}$ The head of the county council gave approval for the study, and copies of the reports of adverse events were handed over to the first author in an anonymous form. All data collected were stored in a locked space to which only the first author had access. 
Table 1. Characteristics of the complaints concerning communication related to public and private healthcare

\begin{tabular}{lll}
\hline Variable & & $\begin{array}{l}\text { Number of complaints } \\
\text { (N = 115) }\end{array}$ \\
\hline \multirow{4}{*}{ Content } & Hospital healthcare & 72 \\
& - Somatic healthcare & 63 \\
& - Psychiatric healthcare & 9 \\
& Primary healthcare & 31 \\
& Psychiatric care for children & 4 \\
& Dental care & 3 \\
& SOS Alarm Centre & 3 \\
& Rehabilitation & 2 \\
Professional & Physician & 58 \\
level & Registered nurse & 17 \\
& Paramedics & 3 \\
& SOS Alarm Centre staff & 3 \\
& Physiotherapist & 2 \\
& Social worker & 1 \\
& Missing information & 31 \\
\hline
\end{tabular}

\subsection{Data analysis}

Qualitative content analysis was used to categorize essential regularities and meanings in the data, in order to improve knowledge and understanding of the phenomenon in question. ${ }^{[23]}$

First, the texts were read several times to obtain a sense of the whole. ${ }^{[23]}$ Secondly, the texts were sorted into two broad content areas: 1) complaints concerning communication; 2) consequences of the complaints concerning communication. Thirdly, the text in each section of contents was given separate codes. Finally, the codes were compared for differences and similarities, and were grouped into subcategories and categories.

To make the study more rigorous, the following steps were taken: 1) Credibility was ensured throughout the analytical process by constant reading and reflection. The subcategories and categories were described and named as closely as possible to the text;2) Dependability was ensured by describing the methodological process as clearly as possible. ${ }^{[23]}$

\section{Results}

The analysis of patients' and relatives' complaints showed that inadequate communication, inadequate individualistic and holistic healthcare, and unprofessional attitudes were cited as major dimensions of poor communication. The complaints had both a negative and a positive impact on the organization of healthcare (see Table 2).

\section{Discussion}

Patients' and relatives' complaints concerning communication between healthcare staff and patients included inadequate communications, inadequate individualistic and holistic healthcare and unprofessional attitudes during healthcare encounters. The consequence was that patients did not receive safe or quality healthcare. Two types of impact of this poor and inadequate communication emerged from the patients' stories: (a) negative consequences in the form of delayed treatment and investigation, with a negative impact on the person's self-esteem, well-being and use of time/resources, and (b) positive consequences in the sense that the complaints led to organizational changes through redevelopment and the introduction of a dress code at work.

In this study, we found that inadequate communication was related to a lack of written and verbal information, especially from physicians. A previous study ${ }^{[24]}$ investigated patients' health literacy skills and recall of spoken medical instructions. It showed that the majority of patients had adequate health literacy, and that they could correctly recall spoken information. However, another study ${ }^{[25]}$ found that patients' understanding of information was connected both to factors in the patients themselves and to the attitude and self-assessment of physicians. Physicians who promoted the importance of health information for patients had considerably less patients who had difficulties understanding, because they were more likely to be willing to learn about information delivery and adjust their own approaches to help patients understand. ${ }^{[25]}$ This study showed that inadequate communication was also related to the patients' feelings that healthcare staff did not take their experiences seriously, as well as a lack of adequate verbal and written information from the healthcare staff and the fact that some physicians did not speak good Swedish. Previous research has indicated that most complaints about physicians are related to communication barriers, ${ }^{[6]}$ and that patient's desire increased participation and information sharing. ${ }^{[26]}$ A successful, individualized healthcare encounter requires healthcare staff to understand the patient's perspective on his or her illness ${ }^{[2]}$ to avoid the consequences of reduced communication, which can lead to misunderstandings, paving the way for conflict and further miscommunication. ${ }^{[11]}$ Thus, effective communication is the essential core of healthcare, and is fundamental to the delivery of individualised and high-quality, holistic services. ${ }^{[9,27]}$ Effective communication between patients and healthcare staff means adapting communication to the context. This involves taking into account the characteristics of the patient (culture, age and disability), the nature of the communication and broader systems. It recognizes the pressure on healthcare professionals in a difficult health situation. ${ }^{[28]}$ The patients' 
beliefs and values are influenced by social and behavioral fac- of shared meaning ${ }^{[28,30]}$ in which patient's social context, tors as well as biomedical ones. ${ }^{[29]}$ Our findings highlighted the importance of the fact that communication is more than expectations and experiences must be addresses in order to understand the patient's true concerns. ${ }^{[31]}$ an exchange of information. Communication is a process

Table 2. Complaints concerning communication reported from patients and relatives in healthcare

\begin{tabular}{|c|c|c|}
\hline \multicolumn{3}{|c|}{ Complaints concerning communication } \\
\hline $\begin{array}{l}\text { Inadequate } \\
\text { communication }\end{array}$ & Inadequate written information & $\begin{array}{l}\text { Complaints made by patients and relatives, largely about physicians, included poor written information about diagnoses } \\
\text { before and after surgery and prognosis. The lack of adequate written information made participants feel deflated, exposed, } \\
\text { concerned and worried about the management of their surgery and prognosis, and also about delayed treatment and recovery. } \\
\text { Poor written communication was characterized by a lack of information or documentation in the medical record and in the } \\
\text { written invitation letter about procedures regarding medication, pain killers, food and beverage intake before and after } \\
\text { therapy. This resulted in poor preparation, and meant the therapy was delayed or a new appointment had to be made. } \\
\text { Delayed therapy could also lead to patients feeling upset and disappointed. }\end{array}$ \\
\hline $\begin{array}{l}\text { Inadequate } \\
\text { individualistic } \\
\text { and holistic care }\end{array}$ & $\begin{array}{l}\text { Patients' and families' } \\
\text { experiences not believed }\end{array}$ & $\begin{array}{l}\text { Healthcare staff expressed disbelief about the complaints and about people's stories of anxiety and pain, particularly in } \\
\text { healthcare situations where it was difficult to evaluate, diagnose or treat these issues. Some informants felt powerless, and } \\
\text { expressed a sense of grief, anxiety and hopelessness when their stories were not believed and they were denied any further } \\
\text { investigation. In addition, some informants were afraid that serious conditions or the need for treatment might be missed if } \\
\text { healthcare staff were not willing to believe the experiences they mentioned. }\end{array}$ \\
\hline $\begin{array}{l}\text { Inadequate } \\
\text { individualistic } \\
\text { and holistic care }\end{array}$ & $\begin{array}{l}\text { Lack of involvement in } \\
\text { healthcare }\end{array}$ & $\begin{array}{l}\text { In some cases, patients and relatives complained about limited and/or lack of involvement in their healthcare, especially in } \\
\text { situations concerning medical decisions and/or treatments. Being denied involvement in their own and/or their loved ones' } \\
\text { healthcare led to feelings of anxiety and insecurity, as well as negative thoughts for some of the participants. }\end{array}$ \\
\hline $\begin{array}{l}\text { Unprofessional } \\
\text { attitude of } \\
\text { healthcare staff }\end{array}$ & $\begin{array}{l}\text { Unpleasant and nonchalant } \\
\text { attitude }\end{array}$ & $\begin{array}{l}\text { The main problem expressed by patients and families was the unpleasant and nonchalant attitude of healthcare staff. They } \\
\text { felt the healthcare staff seemed heartless with their unfriendly voices and comments, and by doing things which hurt } \\
\text { participants' feelings. }\end{array}$ \\
\hline $\begin{array}{l}\text { Unprofessional } \\
\text { attitude of } \\
\text { healthcare staff }\end{array}$ & Discrimination & $\begin{array}{l}\text { Participants reported a discriminatory attitude from healthcare staff towards patients’ lifestyle, cultural background and } \\
\text { language barriers, which made participants feel humiliated. }\end{array}$ \\
\hline $\begin{array}{l}\text { Unprofessional } \\
\text { attitude of } \\
\text { healthcare staff }\end{array}$ & Lack of empathy & $\begin{array}{l}\text { Some complaints were related to the healthcare staff's lack of empathy when they communicated. This made informants feel } \\
\text { irritated and inferior. }\end{array}$ \\
\hline $\begin{array}{l}\text { Unprofessional } \\
\text { attitude of } \\
\text { healthcare staff }\end{array}$ & No code of confidentiality & $\begin{array}{l}\text { In few cases informants noted that healthcare staff read aloud from the patient's record so that other patients could hear it, } \\
\text { and this meant it was difficult to maintain a code of confidentiality. }\end{array}$ \\
\hline \multicolumn{3}{|c|}{ Consequences of the complaints } \\
\hline $\begin{array}{l}\text { Complaints had } \\
\text { negative and } \\
\text { positive impact } \\
\text { on the healthcare } \\
\text { organization }\end{array}$ & $\begin{array}{l}\text { Negative impact: delayed } \\
\text { treatment and investigation, } \\
\text { negative impact on the patient's } \\
\text { self-esteem and well-being, and } \\
\text { increased use of time/resources }\end{array}$ & $\begin{array}{l}\text { In most cases, patients or relatives had repeated telephone contact with the different healthcare centres before they could get } \\
\text { an appointment to see someone about their problems. In cases where participants were not seen in time, and their problem } \\
\text { became worse, this led to delayed treatment and investigation. This, in turn, could have a negative impact on the } \\
\text { participant's well-being. It could lead to unnecessary costs for medication and incorrect use of resources by healthcare staff. }\end{array}$ \\
\hline $\begin{array}{l}\text { Complaints had } \\
\text { negative and } \\
\text { positive impact } \\
\text { on the healthcare } \\
\text { organization }\end{array}$ & $\begin{array}{l}\text { Positive impact: Organizational } \\
\text { changes in the form of } \\
\text { redevelopment and introduction } \\
\text { of a dress code at work }\end{array}$ & $\begin{array}{l}\text { Another consequence of identifying problems involving communication in the health service was that the complaints were } \\
\text { used to improve patient safety and healthcare quality. This involved organizational changes in the form of policy change. } \\
\text { One example involved establishing a standard dress code for workers in the psychiatric department, to comply with the } \\
\text { county council's existing policy. Furthermore, managers provided ongoing training for healthcare staff on the importance of } \\
\text { a professional attitude during healthcare encounters. }\end{array}$ \\
\hline
\end{tabular}

This study found not only those complaints that were influenced by inadequate communication, but also that negative encounters were influenced by the unprofessional, nonchalant and discriminatory attitude of healthcare staff. These results mirror those of a previous studies ${ }^{[8,11,15]}$ which investigated users' perception of the healthcare encounter, with a special focus on negative encounters and feeling wronged. Physicians were more respectful to patients they respected, and communicated more easily with them. ${ }^{[32]}$ Unfortunately, it has been shown that a lack of professionalism may be underpinned by a negative attitude towards patient categories with perceived low prestige, such as psychiatric illness and chronic pain conditions. ${ }^{[33]}$ Furthermore, unprofessional attitudes may result from disagreements between patients and healthcare staff about roles, particularly in the case of physicians. In the case of rare diseases, healthcare staff may feel they have insufficient expertise to be able to treat them, yet the patient often becomes an expert in his particular illness. ${ }^{[34]}$ Nevertheless, individualised and holistic healthcare includes fair, equal and impartial treatment irrespective of disease, age, ethnic and cultural origin or geographic and regional differences. This should ensure effective, safe and high-quality healthcare and improve healthcare outcomes. ${ }^{[9,10]}$ Positive, respectful treatment means that patients and relatives are involved in care and can participate in decisions concerning treatment. ${ }^{[9,10,35]}$ Healthcare staff 
who have an emphatic approach, ${ }^{[35]}$ expertise in caring and competence in involving with patients have the ability to create a good relationship with each patient. ${ }^{[36]}$

An interesting finding in this study was that communication complaints had there was both a negative and a positive impact on organisation in terms of the quality and safety of healthcare. Patient quality and safety involve a good structure for systematically collecting, analyzing and publicizing criticism and complaints related to healthcare. ${ }^{[10,19]}$ However, it has been noted that criticism and complaints from patients $^{[11,12]}$ as well as healthcare professionals ${ }^{[12,13]}$ concerning adverse events go underreported. The purpose of healthcare is to develop procedures for quality and safe care to reduce the risk of communication barriers and unprofessional attitudes, and to avoid harm to the patients. This has led to the development of individualistic and holistic healthcare. Thus, the opportunity to learn from these complaints may be a prerequisite for improving clinical practice and providing knowledge about where it is failing. [37]

The strategy for the investigation was based on participatory research. The advantages of this include developing stronger relations between the community and academia to ensure that research questions remain relevant. It also increases the capacity of data collection and analysis, and enhances programme recruitment, sustainability and extension. ${ }^{[17]} \mathrm{A}$ potential problem with the chosen design could be disagreement between partners. However, the collaboration in this study maintained a climate of mutual respect, that allowed the researchers to capture a range of voices and experiences. ${ }^{[17]}$

The other strength of the study was its ability to reproduce the rich descriptive content of the patients and relatives' complaints. The documentation involved a review of 115 reports

\section{REFERENCES}

[1] Bredart A, Bouleuc C, Dolbeault S. Doctor-patient communication and satisfaction with care in oncology. Current opinion in oncology. 2005; 17(4): 351-4. Epub 2005/06/04. PMid: 15933466.

[2] Teutsch C. Patient-doctor communication. The Medical clinics of North America. 2003; 87(5): 1115-45. Epub 2003/11/19. PMid: 14621334

[3] Priebe S, Dimic S, Wildgrube C, et al. Good communication in psychiatry - a conceptual review. European Psychiatry. 2011; 26(7): 403-407.

[4] Ha JF, Longnecker N. Doctor-patient communication: a review. The Ochsner Journal. 2010; 10(1): 38-43. PMid: 21603354.

[5] Thorne SE, Harris SR, Mahoney K, et al. The context of health care communication in chronic illness. Patient Educ Couns. 2004; 54(3): over two years, and included a number of events and healthcare professionals with a variety of background experience and skills in the different clinical areas of healthcare. The findings can contribute to improving knowledge about decision makers' and service providers' ability to mobilise resources, improve policies and enhance clinical practice. ${ }^{[17]}$ The findings are contextual and cannot be generalised as they involved a qualitative approach, but as several patients' and relatives' groups made similar complaints and gave a similar picture of their experiences, the results can be transferred to other contexts with similar characteristics. ${ }^{[23]}$

\section{Conclusion}

This study further strengthens the notion of communication in healthcare. The core complaints were related to inadequate written and verbal communication, inadequate individualistic and holistic healthcare, and unprofessional attitudes. The complaints produced both negative and positive impacts on the organisation of healthcare. The opportunity to learn from these complaints is therefore a prerequisite for improving knowledge about where healthcare practice is failing, towards policy which guarantees safe and high-quality healthcare.

\section{Authors' COnTributions}

First author was responsible for the study conception, design and coordination. Further, the first author carried out the data collection, performed the data analyses and drafted and revised the manuscript. Both authors performed the drafting of the manuscript.

\section{ACKNOWLEDgements}

The authors are grateful to the County Council Patients' Advisory Committee, Sweden.
299-306. Epub 2004/08/25. PMid: 15324981. http://dx.doi.o $\mathrm{rg} / 10.1016 / \mathrm{j} \cdot \mathrm{pec} .2003 .11 .009$

[6] Clack GB, Allen J, Cooper D, et al. Personality differences between doctors and their patients: implications for the teaching of communication skills. Medical education. 2004; 38(2): 177-86. Epub 2004/02/12. PMid: 14871388.

[7] Fentiman IS. Communication with older breast cancer patients. Breast J. 2007; 13(4): 406-9. Epub 2007/06/27. PMid: 17593046. http://dx.doi.org/10.1111/j.1524-4741.2007.00449.x

[8] Jangland E, Gunningberg L, Carlsson M. Patients' and relatives' complaints about encounters and communication in health care: evidence for quality improvement. Patient Educ Couns. 2009; 75(2): 199-204. Epub 2008/11/29. PMid: 19038522. http://dx.doi.org/10.10 $16 / j \cdot$ pec. 2008.10 .007

[9] SFS. Hälso- och sjukvårdslagen (The Swedish Health and Medical 
Services Act): Socialstyrelsen (The National Board of Health and Welfare); 1982: 763 [cited 201418 March]. Available from: http://www.riksdagen.se/sv/Dokument-Lagar/Lagar/S venskf orfattningssamling/Halso--och-sjukvardslag-1 982_sfs-1982-763/

[10] World Health Organization. Human rights, health, and poverty reduction strategies [Elektronisk resurs]: World Health Organization; 2008. 1 pdf-fil (xi, 73 s. p.

[11] Wessel M, Lynoe N, Juth N, et al. The tip of an iceberg? A crosssectional study of the general public's experiences of reporting healthcare complaints in Stockholm, Sweden. Bmj Open. 2012; 2(1). PMid: ISI: 000315037200037. http://dx.doi:10.1136/bmjopen-201 1-000489

[12] Christiaans-Dingelhoff I, Smits M, Zwaan L, et al. To what extent are adverse events found in patient records reported by patients and healthcare professionals via complaints, claims and incident reports? BMC Health Serv Res. 2011; 11: 49. Epub 2011/03/02. PMid: 21356056. http://dx.doi.org/10.1186/1472-6963-11-49

[13] Lawton R, Parker D. Barriers to incident reporting in a healthcare system. Quality \& safety in health care. 2002; 11(1): 15-8. Epub 2002/06/25. PMid: 12078362.

[14] Reader TW, Gillespie A, Roberts J. Patient complaints in healthcare systems: a systematic review and coding taxonomy. BMJ quality \& safety. 2014; 23(8): 678-89. Epub 2014/05/31. PMid: 24876289. http://dx.doi:10.1136/bmjqs-2013-002437

[15] Wofford MM, Wofford JL, Bothra J, et al. Patient complaints about physician behaviors: a qualitative study. Academic medicine : journal of the Association of American Medical Colleges. 2004; 79(2): 134-8. Epub 2004/01/28. PMid: 14744713.

[16] Hadziabdic E, Heikkila K, Albin B, et al. Problems and consequences in the use of professional interpreters: qualitative analysis of incidents from primary healthcare. Nursing inquiry. 2011; 18(3): 253-61. PMid: 21790876. http://dx.doi:10.1111/j.1440-1800.20 $11.00542 . \mathrm{x}$

[17] Cargo M, Mercer SL. The value and challenges of participatory research: strengthening its practice. Annual review of public health. 2008; 29: 325-50. Epub 2008/01/05. PMid: 18173388. http://dx.doi.org/10.1146/annurev.pub lhealth.29.091307.083824

[18] Statistiska centralbyrån. Tabeller över Sveriges befolkning $2009=$ [Tables on the population in Sweden 2009]. Örebro: Statistiska centralbyrån; 2010. 485 s. p.

[19] SOSFS. Ledningssystem för kvalitet och patientsäkerhet i hälso- och sjukvården (National Board of Health and Welfare rules on management systems for quality and patient safety in healthcare) Socialstyrelsen (The National Board of Health and Welfare); 2005:12. [cited 201412 May]. Available from: http://www.sls.se/glo $\mathrm{bal} / \mathrm{cpd} /$ SOSFS\%202005_12.pdf

[20] Socialstyrelsen. Lägesrapport inom patientsäkerhetsområde (Status report in field of patient safaty): Socialstyrelsen (The National Board of Health and Welfare); 2014 [cited 201412 May] Available from: http://www.socialstyrelsen.se/Lists/Art ikelkatalog/Attachments/19417/2014-4-7.pdf

[21] SFS. Förordning om etikprövning av forskning som avser människor (Swedish law: Regulation of ethical research involving humans). 2003. 460 [cited 201015 March]. Available from: http://www.riksdagen.se/webbnav/index.aspx?ni $d=3911 \&$ bet $=2003: 460$
[22] World Medical Association Declaration of Helsinki. 2008. Available from: http://www.wma.net/e/policy/b3.htm. Accessed 19 May 2009.

[23] Patton MQ. Qualitative Research \& Evaluation Methods. 3th edition ed. London: SAGE Publications; 2002.

[24] McCarthy DM, Waite KR, Curtis LM, et al. What did the doctor say? Health literacy and recall of medical instructions. Med Care. 2012; 50(4): 277-82. Epub 2012/03/14. PMid: 22411440. http://dx.doi.org/10.1097/MLR.0b013e318241e8e1

[25] Lukoschek P, Fazzari M, Marantz P. Patient and physician factors predict patients' comprehension of health information. Patient Educ Couns. 2003; 50(2): 201-10. Epub 2003/06/05. PMid: 12781935.

[26] Suarez-Almazor ME. Patient-physician communication. Current opinion in rheumatology. 2004; 16(2): 91-5. Epub 2004/02/11. PMid: 14770091.

[27] Socialstyrelsen. Hälso- och sjukvårdsrapport (Health care report) [Non-fiction]. Stockholm: Socialstyrelsen (The National Board of Health and Welfare); 2009 [cited 20141 July]. Available from: http://proxy.lnu.se/login?url=http://search.ebsco host. com/login. aspx?direct $=$ true\&db=cat00750a\&AN=li neu $.265096 \& l$ ang $=s v \&$ site $=$ eds -1 ive\&s cope=site

[28] Wright KB, Sparks L, O'Hair D. Health communication in the 21st century. 2. [rev. and updated] ed. Chichester, West Sussex: WileyBlackwell; 2013. viii, 350 s. p.

[29] Helman C. Culture, health and illness. 4th edition ed. London: Hodder Arnold; 2007.

[30] Craig RT. Communication theory as a Field. Commun Theor. 1999; 9(2): 119-61. http://dx.doi.org/10.1186/1472-6963-10-1 62

[31] Tongue JR, Epps HR, Forese LL. Communication skills. Instructional course lectures. 2005; 54: 3-9. Epub 2005/06/14. PMid: 15948430.

[32] Beach MC, Roter DL, Wang NY, et al. Are physicians' attitudes of respect accurately perceived by patients and associated with more positive communication behaviors? Patient Educ Couns. 2006; 62(3): 347-54. Epub 2006/07/25. PMid: 16859867. http: //dx.doi.org/10.1016/j.pec.2006.06.004

[33] Album D, Westin S. Do diseases have a prestige hierarchy? A survey among physicians and medical students. Soc Sci Med. 2008; 66(1): 182-8. Epub 2007/09/14. PMid: 17850944. http://dx.doi.org $/ 10.1016 / \mathrm{j}$. socscimed.2007.07.003

[34] Budych K, Helms TM, Schultz C. How do patients with rare diseases experience the medical encounter? Exploring role behavior and its impact on patient-physician interaction. Health Policy. 2012; 105(2-3): 154-64. Epub 2012/04/03. PMid: 22464590. http://dx.doi.org/10.1016/j.healthpol.2012.02.018

[35] von Bultzingslowen I, Eliasson G, Sarvimaki A, et al. Patients' views on interpersonal continuity in primary care: a sense of security based on four core foundations. Family practice. 2006; 23(2): 210-9. Epub 2005/12/20. PMid: 16361395. http://dx.doi.org/10.1093/f ampra/cmi103

[36] Halldorsdottir S. The dynamics of the nurse-patient relationship: introduction of a synthesized theory from the patient's perspective. Scand J Caring Sci. 2008 Dec; 22(4): 643-52. Epub 2008 Sep 18. http://dx.doi.org/10.1111/j.1471-6712.2007.00568.x

[37] World Health Organization: Draft Guidelines for Adverse Event Reporting and Learning Systems. 2005 [cited 201430 June]. Available from: http://www. who. int/patientsafety/events/05/ Reporting_Guidelines.pdf?ua $=1$ 